\title{
Developmental Practice Methods: Domain Editors
}

\section{Dana Fusco, $P h D$}

Dana Fusco received her doctoral degree in educational psychology from the Graduate Center of the City University of New York. She is currently an associate professor at York College and served there as the acting dean for the School of Health \& Behavioral Sciences for the past four years. She has extensive experience researching and evaluating youth programs and herself was a youth worker before entering graduate school. With multiple presentations and publications, her latest book, Advancing Youth Work: Current Trends, Critical Questions, is the first anthology of the field and takes a critical look at emergent trends and issues related to the professionalization of youth work as a field, a profession, and a discipline. With abundant cuts to youth services across the globe, her most recent thinking urges us to also consider youth work as a movement.

\section{Karen VanderVen, $P h D$}

Karen VanderVen is professor emerita and past director of the Program in Child Development and Child Care at the University of Pittsburgh. Her writings in the areas of early childhood education include dynamical systems theory and its applications; professionalization, including career, curriculum, and leadership development; play and activity; and lifespan and intergenerational issues have been published in journals and edited books in the field. She serves on the editorial boards of six journals, is the author of over 200 publications on child-related issues, has received several national awards for her work in professionalizing practice with children and youth, and has presented all over the world.

\section{Varda Mann-Feder, $D E d$}

Varda R. Mann-Feder is associate professor of applied human sciences at Concordia University in Montreal, Quebec. From 2004 to 2007, she served as Chair of the Department, an interdisciplinary unit committed to training practitioners at the undergraduate level. Varda served on the Task Force for Educational Accreditation, and has been involved in the child and youth care field since 1976. She began her career as a consulting psychologist in the child welfare system in Montreal, where she consulted with numerous residential, child and youth care, and youth protection teams, and provided training and team building workshops. She has served as: a board member for the Association for Child and Youth Care Practice (U.S.A), Research Chair for the Quebec Association of Educators and was editor of the Journal of Child and Youth Care Work from 2000-2007. Varda has worked with the National Youth in Care Network as a research consultant and has served as an external re- 
viewer for the School of Child and Youth Care at Ryerson University. She is currently active as a member of the Steering Committee for the Society for the Study of Emerging Adulthood, a member of the Publications Committee of the International Federation of Educative Communities (FICE), and as an editorial board member for three peer reviewed journals. 